\title{
The viability of probiotics as a factor influencing the immune response in the Nile tilapia, Oreochromis niloticus
}

\author{
Magda M. El-Ezabi ${ }^{1}$; Sabry S. El- Serafy ${ }^{1}$; Mohamed A. Essa ${ }^{2}$; \\ Santoch Lall ${ }^{3}$; Said M. Daboor ${ }^{2,4}$ and Neven A. Esmael ${ }^{2,3}$ \\ 1- Zoology Department, Faculty of science, Benha University. \\ 2- National, Institute of Oceanography and Fisheries, Cairo, Egypt, \\ 3- Institute of Marine Biosciences, National Research Council of Canada, \\ Halifax, Nova Scotia, Canada \\ 4- Process Engineering and Applied Science, Dalhousie University, Halifax, \\ Nova Scotia, Canada
}

\begin{abstract}
The present investigation was conducted to study the effect of dietary supplementation of the probiotics Bacillus subtilis, Lactobucillus plantarum, a mixture of both bacterial isolates (B.subtilis and L. plantarum) and the yeast, Sacchromyces cerevisiae on the immune response of the Nile tilapia, Oreochromis niloticus. Two experimental diets were conducted. In the first experiment $O$. niloticus ( $24.55 \pm 0.03 \mathrm{~g}$ ) were fed for 60 days on four experimental diets supplemented with $B$. subtilis $\left(10^{7} \mathrm{CFU} / \mathrm{g}\right)$ (D1), $L$. plantarum $\left(10^{7} \mathrm{CFU} / \mathrm{g}\right)(\mathrm{D} 2)$ a mixture of B. subtilis and L. plantarum (D3) and the yeast Sacchromyces cerevisiae (D4) and a control non-supplemented diet. All of the four experimental diets showed significantly increased phagocytic activity, acid phosphatase activity, lysozyme activity and total immunoglobulin activity in blood samples of the fish as compared with the control nonsupplemented diet. In the second experiment, O. niloticus $(35.05 \pm 0.01 \mathrm{~g})$ were fed on a diet supplemented with three concentrations of L. plantarum $\left(10^{5}, 10^{7}\right.$ and $10^{9} \mathrm{CFU} / \mathrm{g}$ ) (D1, D2 and D3) respectively for 60 days. The probiotic treatment increased significantly the phagocytic activity for fish fed D2, while acid phosphatase activity was significantly increased for fish fed D3. Diets (D2 and D3) showed significantly the highest levels of lysozyme activity. No significant differences between the three diets for phenoloxidase activity, while total immunoglobulin showed significantly increased levels for fish fed D1 and D3 respectively. The results of the present study support the use of probiotics as immunostimulants in common fish diets.
\end{abstract}

Keywords: Nile tilapia, Oreochromis niloticus, immunity, probiotics, fish diet.

\section{INTRODUCTION}

The wide use of antibiotics and chemotherapeutics to prevent and control bacterial diseases in fish farms has led to some problems like drug resistance (Alderman and Hastings, 1998; Teuber, 2001). These antibiotics may cause 
inhibition of beneficial microbiota which is normally present in the digestive tract of the fish (Sugita et al., 1991). Moreover, vaccines cannot be used alone as a universal disease control measure in aquaculture (Amábile-Cuevas et al., 1995) due to their limited availability in few countries and their pathogen specific protective action for certain specific bacterial and viral diseases (FAO, 2006). Hence, the use of probiotics as biological control agents or as dietary live microbial supplements in commercial fish culture to improve growth and immune function of the fish (Gatesoupe, 1999; Irianto and Austin, 2002; Kesarcodi-Watson et al., 2008). These potentially probiotic cultures stimulate the growth of preferred microorganisms, out competes with potentially harmful bacteria and reinforce the organisms natural defense mechanisms. Furthermore, lactic acid bacteria (LAB) have been found to exhibit a wide range of physiological, nutritional and therapeutic effects including immunomodulation (Gill,1998) and antibiotic resistance characteristics (Charteris et al., 1998).

The dietary addition of different Lactobacillus species has been applied in some investigations. It has been found that the addition of a probiotic bacteria $L$. rhamnosus (ATCC 53103) to rainbow trout Oncorhyncus mykiss diet could reduce mortality of fish challenged with a virulent strain of Aeromonas salmonicida (Nikoskelainen et al., 2001). The immune system response in rainbow trout, Oncorhyncus mykiss was also improved by the administration of probiotic bacteria L. rhamnosus (JCM 1136) in feed (Panigrahi et al., 2004 and 2005).

Natural immunostimlants are valuable for activating the fish immune system and protecting fish against adverse conditions (Anderson et al., 1995; Sakai et al., 2001). Among them, the yeast Saccharomyces cerevisiae has been found to be a good enhancer of the fish immune system (Siwicki et al., 1994). S. cerevisiae contains various immunostimulating compounds such as $\beta$-glucans, nucleic acids as well as oligosaccharides and it has the capability to enhance immune responses (Ortuno et al., 2002) as well as promoting growth (Li et al., $2004 \& 2005$ ) of various fish species.

Most studies on the use of probiotics for aquaculture have been focused on the use of single bacterium at one or more doses. However, comparative evaluation of multistrains and multispecies probiotics in fish is yet lacking. Among the questions to be answered is whether or not the immune stimulation promoted by combinations of two or more bacteria differs from that elicited by monospecies preparations. In this sense, the present study embodies two experimental trials, the first is to assess the possible modulation of Nile tilapia, Oreochromis niloticus immune parameters by dietary supplementation of different probiotics (B. subtilis NIOFSD017, L. plantarum NIOFSD018, either singly or a mixture containing both bacterial isolates, and the yeast Saccharomyces cerevisiae NIOFSD019 isolated from healthy O. niloticus fish in order to evaluate their effect on the immune response. The second trial is 
designed to determine the optimum probiotic dose of the talent bacterial isolate selected based on the results of the first trial.

\section{MATERIALS AND METHODS}

\section{Isolation and selection of microbial flora from $O$. niloticus gut.}

Several microbial species were isolated from intestine of ten apparently healthy O. niloticus fish, using the method of Trust and Sparrow (1974). One ml of ten fold dilutions seeded on Tryptone Soya Agar (TSA, 1-200, Scharulu Chemie, Barcelona, Spain), De Man, Rogosa and Sharpe (MRS, 1-135, Scharulu Chemie, Barcelona, Spain) and Yeast Peptone Dextrose Agar (YPD, 1-473, Scharulu Chemie, Barcelona, Spain). The plates were incubated at $35 \pm 2^{\circ} \mathrm{C}$ for 24 to $72 \mathrm{~h}$. based on the microorganisms type. The anaerobic counts were determined by incubated anaerobic agar (1-371, Scharulu Chemie, Barcelona, Spain) plates at $35 \pm 2{ }^{\circ} \mathrm{C}$ for three days in anaerobic conditions using anaerobic chamber with $5 \% \mathrm{CO}_{2}$ and relative humidity of $50 \%$ (Daboor, 2008). The authenticity of the microbial cultures were verified by sub-culturing several times on the same medium and stored at $4{ }^{\circ} \mathrm{C}$ for further use. A common way to select probiotic isolates was carried out according to Vine et al. (2004) selecting those with the ability to produce secondary metabolites.

Three selected colonies: NIOFSD017, NIOFSD018 (bacterial isolates) and NIOFSD019 (yeast) were characterized and identified following the criteria described in Bergey's Manual of Determinative Bacteriology (Holt et al., 1994) and in parallel to commercial API $50 \mathrm{CH}$ and API 20 CAUX (Bio-Merieux, Marcy I Etoile, France) for bacteria and yeasts, respectively.

B. subtilis (NIOFSD017), L. plantarum (NIOFSD018) and $S$. cerevisiae (NIOFSD019) were grown aseptically in $10 \mathrm{ml}$ of nutrient, MRS and YPD broth for $24 \mathrm{~h}$. at $35 \pm 2^{\circ} \mathrm{C}$. Five $\mathrm{ml}$ were transferred under aseptic conditions into $250 \mathrm{ml}$ of nutrient, MRS and YPD broths and held on a shaker at $150 \mathrm{rpm}$ for $24-48 \mathrm{~h}$. at $35 \pm 2{ }^{\circ} \mathrm{C}$. The cells of each isolate were harvested by centrifugation at $10.000 \mathrm{rpm}$ at $4{ }^{\circ} \mathrm{C}$ for $15 \mathrm{~min}$. and washed twice with phosphate buffer (PB) having $\mathrm{pH} 7.0$, then dispensed in $5 \mathrm{ml} \mathrm{PB}$.

\section{Experiment 1: Fish and experimental design}

One hundred ninety two Nile tilapia, $O$. niloticus $(24.55 \pm 0.03 \mathrm{~g})$ of both sexes were used in this experiment. Fish were brought from a private fish farm at Giza, Egypt. They were transferred to the laboratory aquaria and acclimated for 14 days prior to the experiments and they were fed with basal diet. Fish were distributed in five experimental groups with each of two replicates in indoor concrete ponds at a density of 15 fish $\mathrm{m}^{-3}$ according to a completely randomized design. Aeration was provided by an air pump for each pond. Water was partially changed every 3 days and entirely every week. Fish were fed three times per day ( $3 \%$ of body weight) during this period. Water quality of ponds was analyzed following the method of APHA (1995). 
The dry ingredients were mixed with corn oil and the microbial isolates were incorporated into the feed diet components according to Salinas et al. (2005) as shown in tables (1\&2). After a desirable dough quality was obtained, diets were passed through a mincer with a die $(3 \mathrm{~mm}$ diameter) and the resulting spaghetti-like strings were dried until the moisture levels were at approximately $10 \%$. The diets were then stored in a $-15^{\circ} \mathrm{C}$ freezer until being used.

In this experimental trial, the effect of different probiotic isolates includeing $B$. subtilis (NIOFSD017 $10^{7} \quad \mathrm{CFUg}^{-1}$ ) (D1), L. plantarum (NIOFSD018 $10^{7} \mathrm{CFUg}^{-1}$ ) (D2), a mixture containing bacterial isolates (NIOFSD017 and NIOFSD018) (D3) and yeast S. cerevisiae (NIOFSD019 10 $\left.\mathrm{CFUg}^{-1}\right)(\mathrm{D} 4)$ were used as dietary supplements for Nile tilapia in addition to the control diet (probiotic free diet) in order to determine their effect on the immune response of the fish.

Table 1: Formulation and composition of the experimental diets (dry matter basis) used to fed the Nile tilapia in the first experimental study

\begin{tabular}{|c|c|c|c|c|c|}
\hline \multirow[t]{2}{*}{ Ingredients } & \multirow{2}{*}{$\begin{array}{c}\text { Composition (\%) } \\
\text { Control }\end{array}$} & \multicolumn{4}{|c|}{ Probiotic diets } \\
\hline & & D1 & D2 & D3 & D4 \\
\hline Fish meal & 30.0 & 30.0 & 30.0 & 30.0 & 30.0 \\
\hline Soybean meal & 22.5 & 22.5 & 22.5 & 22.5 & 22.5 \\
\hline Wheat bran & 38.0 & 38.0 & 38.0 & 38.0 & 38.0 \\
\hline Corn oil & 5.00 & 5.00 & 5.00 & 5.00 & 5.00 \\
\hline Vitamin and minerals premix ${ }^{1}$ & 2.00 & 2.00 & 2.00 & 2.00 & 2.00 \\
\hline Starch & 2.0 & 2.0 & 2.0 & 2.0 & 2.0 \\
\hline Chromic oxide & 0.5 & 0.5 & 0.5 & 0.5 & 0.5 \\
\hline B. subtilis NIOFSD017 $\mathrm{CFUg}^{-1}$ & & $10^{7}$ & & & \\
\hline L. plantarum NIOFSD018 CFUg ${ }^{-1}$ & & & $10^{7}$ & & \\
\hline $\begin{array}{l}\text { Mixture of B. subtilis NIOFSD017 and } L \text {. } \\
\text { plantarum NIOFSD018 CFUg }{ }^{-1} 2\end{array}$ & & & & $10^{7}$ & \\
\hline S. cerevisiae NIOFSD019 $\mathrm{CFUg}^{-1}$ & & & & & $10^{4}$ \\
\hline \multicolumn{6}{|l|}{ Chemical composition } \\
\hline Moisture & \multicolumn{5}{|l|}{11.20} \\
\hline Crude protein & \multicolumn{5}{|l|}{30.02} \\
\hline Ether extract & \multicolumn{5}{|l|}{10.35} \\
\hline Ash content & \multicolumn{5}{|l|}{11.85} \\
\hline Crude fiber & \multicolumn{5}{|l|}{7.10} \\
\hline Nitrogen free extract & \multicolumn{5}{|l|}{40.68} \\
\hline Growth energy $(\mathrm{kcal} . / \mathrm{kg})^{3}$ & \multicolumn{5}{|l|}{4382.76} \\
\hline
\end{tabular}

1. Vitamins and Minerals premix, Kg of premix contained, vit. A (4000 000 IU), vit.D (666 666.7 IU), vit. E $(3333.3 \mathrm{mg})$, vit. $\mathrm{K}_{3}(333.3 \mathrm{mg})$, thiamin $(333.3 \mathrm{mg})$, riboflavin $(1666.7 \mathrm{mg})$, vit. $\mathrm{B}_{6}(500 \mathrm{mg})$, vit. $\mathrm{B}_{12}(3.33$ $\mathrm{mg})$, pantothenic acid $(3333.3 \mathrm{mg})$, folic acid $(333.3 \mathrm{mg})$, Biotin $(16.7 \mathrm{mg})$ Niacin $(10000 \mathrm{mg})$, Iron (10000 $\mathrm{mg})$, manganese $(20000 \mathrm{mg})$, copper $(1333.3 \mathrm{mg})$, zinc $(166666.7 \mathrm{mg})$, iodine $(100 \mathrm{mg})$, cobalt $(33.3 \mathrm{mg}) \mathrm{and}$ selenium(33.3mg).

2. The mixture contains B. subtilis NIOFSD017; $0.5 \times 10^{7} \mathrm{CFU}^{\mathrm{g}-1}$ \& L. plantarum NIOFSD018; 0.5 $\times 10^{7} \mathrm{CFUg}^{-1}$. 3. Gross Energy $(\mathrm{Kcal} / \mathrm{Kg})=[5.65(\mathrm{CP} \%)+9.45(\mathrm{EE} \%)+4.2(\mathrm{NEF} \%) \times 1000 / 100]($ Hepher et al., 1983). D1: B. subtilis NIOFSD017, D2: L. plantarum NIOFSD018, D3: Mixture of B. subtilis NIOFSD017; $0.5 \times 10^{7}$ $\mathrm{CFU} \mathrm{g}^{-1}$ and L. plantarum NIOFSD018; $0.5 \times 10^{7}$ CFUg, D4: S. cerevisiae NIOFSD019. 
Table 2: Formulation and composition of the experimental diets (dry matter basis) used to fed the Nile tilapia in the second experimental study

\begin{tabular}{|c|c|c|c|c|}
\hline \multirow[t]{2}{*}{ Ingredients } & \multirow{2}{*}{$\begin{array}{c}\begin{array}{c}\text { Composition } \\
(\%)\end{array} \\
\text { Control }\end{array}$} & \multicolumn{3}{|c|}{ Probiotic diets } \\
\hline & & D1 & D2 & D3 \\
\hline Fish meal & 26.0 & 30.0 & 30.0 & 30.0 \\
\hline Soybean meal & 25.5 & 22.5 & 22.5 & 22.5 \\
\hline Wheat bran & 38.0 & 38.0 & 38.0 & 38.0 \\
\hline Corn oil & 5.00 & 5.00 & 5.00 & 5.00 \\
\hline Vitamin and minerals premix ${ }^{1}$ & 2.00 & 2.00 & 2.00 & 2.00 \\
\hline Starch & 3.00 & 2.0 & 2.0 & 2.0 \\
\hline Chromic oxide & 0.50 & 0.5 & 0.5 & 0.5 \\
\hline L. plantarum $_{\mathrm{NIOFSD} 018} \mathrm{CFUg}^{-1}$ & & $10^{5}$ & $10^{7}$ & $10^{9}$ \\
\hline \multicolumn{5}{|l|}{ Chemical composition } \\
\hline Moisture & \multicolumn{4}{|l|}{10.75} \\
\hline Crude protein & \multicolumn{4}{|l|}{30.42} \\
\hline Ether extract & \multicolumn{4}{|l|}{9.68} \\
\hline Ash content & \multicolumn{4}{|l|}{12.30} \\
\hline Crude fiber & \multicolumn{4}{|l|}{6.50} \\
\hline Nitrogen free extract & \multicolumn{4}{|l|}{41.1} \\
\hline Growth energy $(\mathrm{kcal} . / \mathrm{kg})^{2}$ & \multicolumn{4}{|l|}{4359.69} \\
\hline
\end{tabular}

1. Vitamins and Minerals premix, kg of premix contained, vit. A (4000 000 IU), vit.D (666 666.7 $\mathrm{IU})$, vit. $\mathrm{E}(3333.3 \mathrm{mg})$, vit. $\mathrm{K}_{3}(333.3 \mathrm{mg})$, thiamin $(333.3 \mathrm{mg})$, riboflavin $(1666.7 \mathrm{mg})$, vit. $\mathrm{B}_{6}(500$ $\mathrm{mg})$, vit. $B_{12}(3.33 \mathrm{mg})$, pantothenic acid $(3333.3 \mathrm{mg})$, folic acid $(333.3 \mathrm{mg})$, Biotin $(16.7 \mathrm{mg})$ Niacin $(10000 \mathrm{mg})$, Iron $(10000 \mathrm{mg})$, manganese $(20000 \mathrm{mg})$, copper $(1333.3 \mathrm{mg})$, zinc $(166666.7 \mathrm{mg})$, iodine $(100 \mathrm{mg})$, cobalt $(33.3 \mathrm{mg})$ and selenium $(33.3 \mathrm{mg})$.

2. Gross Energy $(\mathrm{Kcal} / \mathrm{Kg}):[5.65(\mathrm{CP} \%)+9.45(\mathrm{EE} \%)+4.2(\mathrm{NEF} \%) \times 1000 / 100]($ Hepher et al., 1983).

D1: L. plantarum NIOFSD018; $10^{5} \mathrm{CFU}^{-1} \mathrm{~g}$, D2: L. plantarum NIOFSD018; $10^{7} \mathrm{CFU}-{ }^{1} \mathrm{~g}, \quad$ D3: $L$. plantarum NIOFSD018; $10^{9} \mathrm{CFU}-{ }^{1} \mathrm{~g}$

\section{Immunological parameters}

Blood samples were scheduled after 60 days of probiotic treatment. A total of 16 fish were taken from each treatment. Blood samples were drawn from the caudal vein of the individual fish without anaesthetization after 24 hours of starvation period. The plasma and serum samples were separated, using standard procedures and preserved at $-20^{\circ} \mathrm{C}$ prior to analysis. The plasma samples were used for the measurement of phagocytic activity, while serum samples were used for determining the acid phosphatase, lysozyme activity, phenoloxidase activity and total immunoglobulin.

\section{Phagocytic activity}

Phagocytic activity of leucocytes was determined according to Puangkaew et al. (2004). Briefly, a $300 \mu \mathrm{l}$ of the leucocyte suspension in L-15 medium (Sigma-Aldrich) containing $2 \times 10^{6} \mathrm{ml}^{-1}$ cells was seeded into a chamber slide (Lab-Tek Nalge Nunc International Co. Ltd. Illinois, USA), the cells were incubated at $15^{\circ} \mathrm{C}$ for two hours and the non-adherent cells were removed. The cells were further incubated for one hour at $15{ }^{\circ} \mathrm{C}$ after adding opsonized 
fluorescent latex beads (2Am; Sigma) to each chamber to maintain the cells to bead ratio of $1: 10$. The latex beads were opsonized by incubating $2 \times 10^{7}$ beads $\mathrm{ml}^{-1}$ with the serum of the corresponding fish. After washing and fixation, the cells were stained with Diff Quick solution (Kokusai Shiyaku Co.Ltd., Hyougo, Japan). The phagocytic activity (PA) was expressed as the percentage of phagocytising cells quantified from 300 adherent cells under microscope.

\section{Acid phosphatase activity}

Acid phosphatase activity was determined using Acid Phosphatase Assay Kit (Cayman Chemical, Catalog Number 10008051).

\section{Lysozyme activity}

Lysozyme activity in the serum was measured by agrose gel cell lysis assay, according to the method described by Schltz (1987). Briefly lysoplates were prepared by dissolving $0.01 \%$ agarose in $0.0067 \mathrm{M}$ PBS (pH 6.3) at 100 ${ }^{\circ} \mathrm{C}$, when agarose temperature reached $60-70{ }^{\circ} \mathrm{C}, 500 \mathrm{mg}$ of uniform suspension of Micrococcus lysodeikticus in $5 \mathrm{ml}$ saline was added to one liter of agrose and mixed well, then the plates were poured, exactly $25 \mu 1$ of each of the serum samples and standard lysozyme solutions were put in each poured well, then the plates were incubated at $28-30{ }^{\circ} \mathrm{C}$ for $12-18 \mathrm{~h}$. and the clear zones ring diameters were measured. The diameters of sample clear zones were plotted against the standard for obtaining lysozyme concentration in unit.

\section{Serum total immunoglobulin}

Serum total immunoglobulin was analyzed through serum protein fractionation. The electrophoretic assay was applied according to the method described by Nils (1983). Briefly, serum proteins were divided into fractions of 4 bands (albumin and $\alpha, \beta$, and $\gamma$ globulin) the quantization of different fractions was conducted using Gelman DCD 16 digital computing densitometer.

\section{Experiment 2:}

In a trial to reach an ideal dose that could be suitable for Nile tilapia culture, the second experiment was conducted using different doses $\left(10^{5}, 10^{7}\right.$ and $10^{9} \mathrm{CFU} / \mathrm{g}$ diet) of L. plantarum (NIOFSD018).

In this experiment, 192 specimens of O. niloticus $(35.05 \pm 0.01 \mathrm{~g})$ were acclimated for living in lab aquarium and to the basal diet as in the first experimental study. Fish were distributed into four experimental groups (three replicates for each group) at a stocking density of 12 fish $\mathrm{m}^{-3}$. The rearing facilities were the same as the first experiment. Fish were fed for 60 days using different doses $\left(10^{5}, 10^{7}\right.$ and $10^{9} \mathrm{CFU} / \mathrm{g}$ diet) of L. plantarum (NIOFSD018) in addition to a control non-supplemented diet in a trial to reach an ideal dose that could be suitable for Nile tilapia culture. Sixteen specimens were sampled at the end of each experimental trial and blood samples were collected as described in the first experiment. The methodology employed for the determination of phagocytic, acid phosphatase activities and total immunoglobulin was the same as in experiment 1 . 


\section{Lysozyme activity}

Lysozyme activity was measured using the turbidimetric assay developed by Parry et al. (1965) and the micro plate adaptation method of Hutchinson and Manning (1996) with some minor modifications. Chicken egg lysozyme (Sigma) was used as a standard. It was dissolved in $40 \mathrm{mM}$ phosphate buffer $(\mathrm{pH}$ 6.2) to make a solution of 2500 units $/ \mathrm{ml}$. A $0.6 \mathrm{mg} / \mathrm{ml}$ suspension of lyophilized Micrococcus lysodeikticus (Sigma) was prepared as substrate. A $25 \mu \mathrm{l}$ of serum sample was added to $25 \mu \mathrm{L}$ of buffer then $50 \mu \mathrm{l}$ of the substrate $(M$. lysodeikticus) was added to give a final volume of $100 \mu \mathrm{L}$. The absorbance (at $450 \mathrm{~nm}$ ) was measured after 0.5 and $4.5 \mathrm{~min}$. The unit of enzyme activity was defined as a reduction in absorbance of $0.001 \mathrm{~min}^{-1} \mathrm{ml}^{-1}$

\section{Phenoloxidase activity}

Phenoloxidase activity was measured spectrophotometrically according to Leonard et al. (1985) with some modifications. This method depends on recording the formation of dopachrome from L-DOPA (L-dihydroxy phenylalanine). The $50 \mu \mathrm{l}$ of serum was preincubated with $50 \mu \mathrm{L}$ of laminarin $(2 \mathrm{mg} / \mathrm{ml})$ for one hour at $20^{\circ} \mathrm{C}$ before $50 \mu \mathrm{l}$ of L-DOPA $(2 \mathrm{mg} / \mathrm{ml})$ was added. The reaction was allowed to proceed for $10 \mathrm{~min}$ at $20{ }^{\circ} \mathrm{C}$, after which the absorbance was measured at $490 \mathrm{~nm}$. The enzyme activity was expressed as the increase in absorbance of $0.001 \mathrm{~min}^{-1} \mathrm{ml}^{-1}$ serum.

\section{Statistical analysis}

Results are expressed as means \pm standard deviation (SDM). Data were statistically analyzed, using one-way analysis of variance (ANOVA). Multiple comparisons among means were made by Duncan's (Duncan, 1955) using SPSS 17 statistical program for Dalhousie University, Halifax, Canada. Differences were considered statistically significant when $\mathrm{P}<0.05$.

\section{Experiment 1}

\section{RESULTS}

After 60 days of feeding the Nile tilapia, O. niloticus with four experimental diets (D1, D2, D3 and D4) containing four different probiotics, all the immune parameters showed significantly higher values than the control, nonsupplemented diet. Fish fed D4 showed statistically the maximun phagocytic activity followed by fish fed diets D2, D3 and D1 respectively (Table 3).

Serum acid phosphatase activity was significantly increased in fish fed diets (D1, D2, D3 and D4) respectively as compared to the control diet (Table 3). The maximum increase in serum acid phosphatase activity was recorded for fish fed D3 (Table3).

All the four experimental diets showed significantly increased values in serum lysozyme activity as compared with fish fed the control diet. Although the maximum value of lysozyme activity $\left(342.35 \pm 20.44 \mathrm{Uml}^{-1}\right)$ was recorded for fish fed diet D3, it was not significantly different from that recorded for fish fed the diets D1 and D2 (Table 3). 
Feeding O. niloticus with four different probiotic diets increased significantly total serum immunoglobulin level. Diet D3 recorded significantly the highest values of total immunoglobulin (Table 3).

Table 3: Immunological parameters of Nile tilapia, O. niloticus fed various probiotic groups $^{1}$

\begin{tabular}{|l|c|c|c|l|l|}
\hline \multirow{2}{*}{\multicolumn{1}{|c|}{ Items }} & \multicolumn{5}{|c|}{ Diets } \\
\cline { 2 - 6 } & Control & D1 & D2 & D3 & D4 \\
\hline Phagocytic activities (\%) & $74.5^{\mathrm{c}}$ & $77.56^{\mathrm{b}}$ & $79.0^{\mathrm{a}}$ & $78.50^{\mathrm{ab}}$ & $79.31^{\mathrm{a}}$ \\
& \pm 1.50 & \pm 1.55 & \pm 1.32 & \pm 1.21 & \pm 1.58 \\
\hline Acid phosphatase activities & $6.76^{\mathrm{c}}$ & $8.14^{\mathrm{a}}$ & $8.11^{\mathrm{a}}$ & $8.27^{\mathrm{a}}$ & $7.05^{\mathrm{b}}$ \\
$(\mathrm{U} / \mathrm{ml})$ & \pm 0.22 & \pm 0.36 & \pm 0.17 & \pm 0.28 & \pm 0.09 \\
\hline Lysozyme activities (U/ml) & $288.60^{\mathrm{c}}$ & $331.18^{\mathrm{ab}}$ & $330.61^{\mathrm{ab}}$ & $342.35^{\mathrm{a}}$ & $327.81^{\mathrm{b}}$ \\
& \pm 13.23 & \pm 19.45 & \pm 14.996 & \pm 20.44 & \pm 21.15 \\
\hline Total immunoglobulin (g/dl) ${ }^{3}$ & $0.998^{\mathrm{c}}$ & $2.055^{\mathrm{a}}$ & $1.70^{\mathrm{b}}$ & $2.115^{\mathrm{a}}$ & $1.80^{\mathrm{b}}$ \\
& \pm 0.038 & \pm 0.107 & \pm 0.137 & \pm 0.238 & \pm 0.060 \\
\hline
\end{tabular}

1. Values (mean \pm standard deviation) in the same raw sharing the same superscript are not significantly different $(\mathrm{P}<0.05), \mathrm{n}=16$

2. D1; B. subtilis NIOFSD017, D2; L. plantarum NIOFSD018, D3; coculture (NIOFSD017 and

NIOFSD018), D4; S. cerevisiae NIOFSD019, and control; microorganisms free

3. $\mathrm{dl}:$ deciliter

\section{Experiment 2}

The effect of $L$. plantarum (NIOFSD018) with three different doses $\left(10^{5}\right.$, $10^{7}$ and $10^{9} \mathrm{CFU} / \mathrm{g}$ diet) on the immune response (phagocytic activity, seum acid phosphatase activity, serum lysozyme activity, total serum immunoglobulin and phenoloxidase activity) of $O$. niloticus are summarized in Table 4. It is obvious that the tested immunological parameters showed varying response to the different probiotic doses. The phagocytic activity was significantly increased by increasing the probiotic dose from $10^{5}$ to $10^{7} \mathrm{CFUg}^{-1}$. However, by increasing the dose of probiotic to $10^{9} \mathrm{CFUg}^{-1}$, the phagocytic activity has decreased again but it was still significantly higher than that of the fish fed the control (Table 4).

Acid phosphatase activity was significantly increased for fish fed diet D3 at the dose of $10^{9} \mathrm{CFU} \mathrm{g}^{-1}$ of $L$. plantarum (NIOFSD018), while there was non significant differences between fish fed diets D1 and D2 (Table 4).

No significant differences appeared in lysozyme activity for fish fed $10^{5}$ $\mathrm{CFUg}^{-1}$ of L. plantarum (NIOFSD018) (D1) and that of the control diet. On the other hand, Nile tilapia received the diets containing $10^{9}$ and $10^{7} \mathrm{CFUg}^{-1}$ of probiotic exhibited the highest average of lysozyme activity respectively (Table $4)$.

As shown in Table (4), the total serum immunoglobulin for fish fed different doses of L. plantarum (NIOFSD018) were significantly increased compared to the control group. The maximum value for total serum immunoglobin was observed for fish fed D2. On the other hand, Phenoloxidase activity (Table 4) was insignificantly increased by each increasing in $L$. plantarum (NIOFSD018) dose. 
From the previous immunological data, it is clear that Nile tilapia, fed D2 $\left(10^{7} \mathrm{CFUg}^{-1}\right)$ had significantly the highest values of phagocytic activity and total immunoglobulin. However, no significant differences were observed in lysozyme activity or phenoloxidase activities between D2 and D3 $\left(10^{7} \mathrm{CFUg}^{-1}\right)$. Acid phosphatase exhibited significantly higher activity in fish fed D3 than fish fed D2.

Table 4: Immunological values of Nile tilapia, O. niloticus fed different concentrations of L. plantarum (NIOFSD018 ${ }^{1}$ )

\begin{tabular}{|l|c|c|c|c|}
\hline \multirow{2}{*}{\multicolumn{1}{|c|}{ Items }} & \multicolumn{4}{|c|}{ Treatments $^{2}$} \\
\cline { 2 - 5 } & Control & D1 & D2 & D3 \\
\hline Phagocytic activities (\%) & $72.72^{\mathrm{c}}$ & $73.39^{\mathrm{c}}$ & $78.5^{\mathrm{a}}$ & $76.67^{\mathrm{b}}$ \\
& \pm 1.36 & \pm 2.12 & \pm 2.20 & \pm 2.45 \\
\hline Acid phosphatase activities $\left(10^{-4}\right.$ & $3.47^{\mathrm{b}}$ & $5.50^{\mathrm{b}}$ & $6.28^{\mathrm{b}}$ & $9.25^{\mathrm{a}}$ \\
U/ml) & \pm 0.91 & \pm 0.31 & \pm 0.07 & \pm 2.90 \\
\hline Lysozyme activities (U/ml) & $80.00^{\mathrm{b}}$ & $128.30^{\mathrm{b}}$ & $889.78^{\mathrm{a}}$ & $913.78^{\mathrm{a}}$ \\
& \pm 42.40 & \pm 49.06 & \pm 89.74 & \pm 93.71 \\
\hline Total immunoglobulin (g/dl) & $1.6597^{\mathrm{c}}$ & $2.0436^{\mathrm{b}}$ & $2.207^{\mathrm{a}}$ & $2.0535^{\mathrm{b}}$ \\
& \pm 0.072 & \pm 0.121 & \pm 0.077 & \pm 0.154 \\
\hline Phenoloxidase activities (U/ml) & $7.93 \mathrm{a}$ & $8.00 \mathrm{a}$ & $8.87 \mathrm{a}$ & $10.67^{\mathrm{a}}$ \\
& \pm 5.06 & \pm 3.40 & \pm 1.03 & \pm 2.47 \\
\hline
\end{tabular}

1. Values (mean \pm standard deviation) in the same column containing different superscripts were significantly different $(\mathrm{P}<0.05), \mathrm{n}=16$ fish.

2. D1; diet having $10^{5}, \mathrm{D} 2 ; 10^{7}, \mathrm{D} 3 ; 10^{9} \mathrm{CFU} / \mathrm{g}$ of L. plantarum NIOFSD018 and Control; probiotic free diet

3. dl: deciliter

\section{DISCUSSION}

By definition, probiotics are living microorganisms, which upon ingestion in certain numbers exert health benefits on the host (Guarner and Schaafsma, 1993). Results obtained in the present study on the immune response of tilapia showed that the immunological parameters were modulated in fish fed the different probiotics. The beneficial effects of probiotics on the modulation of fish immune system have been investigated (Austin et al., 1995; Stosik and Szenfeld, 1996; Rengpipat et al., 2000; Heyman and Me'nard, 2002; and Taoka et al., 2006, Nayak, 2010). It has been shown that the modulation of immune response by probiotics comprised different responses in a variety of domestic animals and fish, including the induction of proinflammatory cytokines, the activation of natural killer cells, production of mucosal and systemic antibodies and increasing the phagocytic lysozyme and complement activities (Miettinen et al., 1996, Matsuzaki and Chin, 2000; and Panigrahi et al., 2004 and 2005). Probiotics treatment provide a wide spectrum of responses and better nonspecific disease protection as a result of both the enhancement of serological immunity and competitive exclusion in host sut (Rengpipat et al., 2000). It has been also reported that vaccination or immunostimulation may provide only short-term protection against specific pathogens (Sung and Song, 1996 and Sung et al., 1996). In addition, the cell wall components of probiotic bacteria, such as 
$\beta$-glucan, lipopolysaccharide and peptidoglycans were attributed to the immunostimulatory effects in fish (Rengpipat et al., 2000, Gullian et al., 2004). B. subtilis, when administered through feed may have an additional advantage as a promising candidate probiotic because of its spore forming ability (Kennedy et al., 1998, Moriarty, 1998; and Querroz \& Boyd, 1998).

Fish fed on a diet supplemented with the different probiotics (D1, D2 and D3) showed a significant increase in phagocytic activity, acid phosphatase activity, lysozyme activity and total serum immunoglobulin compared with fish received the control diet. Lactic acid bacteria (LAB) have been widely used as a dietary supplement to protect fish from various infections (Verschuere et al., 2000). They are considered a safe product for feeding fish. Their ability to improve the immune response against harmful pathogens allows them to be considered as an alternative method to control various fish diseases (Gatesoupe, 1999).

Phagocytic activity is responsible for early activation of the inflammatory response before antibody production and plays an important role in antibacterial defense. Probiotics can effectively trigger the phagocytic cells in host and enhancement of phagocytic activity. Stimulation of phagocytic activity by LAB bacteria supplemented in the diet of $O$. niloticus has already been observed in the present study. Stimulation of phagocytic activity by these probiotics has been found in several fish species (Irianto and Austin, 2002; Panigrahi et al., 2004; Brunt et al., 2007; Pieter et al., 2008). Feeding O. niloticus a diet supplemented with a mixture of $B$. subtilis and $L$. plantarum (D3) stimulated the phagocytic activity of the leukocytes of the fish but it was not the most effective diet. It was suggested that $\mathrm{LAB}$ might mediate the phagocytic activity through modulation of cell surface molecules that are involved in bacterial uptake by leukocytes (Panigrahi et al.,2005).

Acid phosphatase an enzyme localized within lysosomes is important for intracellular digestion of phagocytized antigens and has been used as a marker of macrophages activation in animal modes including fish (Zeng-fu et al., 2006). In the present study, it was observed that an increase in acid phosphatase activity when $O$. niloticus fed the probiotic supplemented diets which indicating that these probiotics could stimulate the immune response of the fish.

In the present study, the significant increase in lysozyme activity of fish fed different probiotics suggests an immune stimulation. Lysozyme, is an enzyme with antibacterial activity that can split peptidoglycan in bacterial cell walls particularly the gram positive species and it can cause lysis of the cells (Chipman and Sharon, 1969). Lysozyme occurs predominantly in fish mucus, serum and tissues rich in leucocytes (Ellis, 1999). Infections or invasion by foreign material could result in an increase in the lysozyme concentration in fish blood (Siwicki and Studnicka, 1987; Moyner et al., 1993).

The total immunoglobulin results showed significantly higher values in fish fed with the different probiotics as compared to the control. This confirms 
that the probiotic bacteria can stimulate the antibody production in fish (Panigrahi et al., 2004). Serum immunoglobulins are major components of the humoral immune system which provide disease protection in animals and human beings (Watts et al., 2001). Panigrahi et al. (2004) reported an increase in total serum immunoglobulin levels of rainbow trout, Oncorhynchus mykiss and the Indian major carp, Labeo rohita, fed diet containing B. subtilis (Nayak et al., 2007). Yeast cells have been found to be effective in increasing the serum immunoglobulin IgM level of seabream, Sparus aurata by its supplementation to the diet as an immunostimulatant (Cuesta et al., 2004).

In this investigation, an improvement in several immunological parameters was obvious mainly due to the administration of Saccharomyces cerevisiae (NIOFSD019) to the diet. Yeasts are capable of specifically adhering to the intestinal mucus membrane of fish (Douglas, 1989; and Vázquez-Juárez et al., 1997). S. cerevisiae contains various compounds such as $\beta$-glucans, nucleic acids and mannan oligosaccharides which are considered as immunostimulating compounds (Siwicki et al., 1994; Anderson et al., 1995; Ortuño et al., 2002). It has been recognized that nucleic acids and $\beta$-1,3-glucans effectively enhanced immune functions of African catfish (Yoshida et al., 1995), Atlantic salmon (Engstad et al.,1992), rainbow trout (Jørgensen et al., 1993; and Siwicki et al., 1994) and shrimp Penaeus monodon (Thanardkit et al., 2002).

The findings of the present study suggest a possible interaction between the two bacterial isolates (B. subtilis and L. plantarum) whereas the highest values for acid phosphatase activity, lysozyme activity and total immunoglobulin were recorded in fish fed D3. Few studies have been undertaken to test the effects of bacterial co-culture as a probiotic in fish. However, the combination of bacterial strains occupy different niches within the gut microflora environment may in turn have desirable effects on the host immune response and health of gilthead sea bream (Salinas et al., 2005) and $O$. niloticus (Aly et al., 2008) .

In the second experimental trial, three doses $\left(10^{5}, 10^{7}\right.$ and $\left.10^{9} \mathrm{CFU} / \mathrm{g}\right)$ of L. plantarum were used. A higher percentage of phagocytic cells were observed in the probiotic fed groups particularly the group of fish fed with $\left(10^{7} \mathrm{CFU} / \mathrm{g}\right)$ bacterium dose. This could be indicating that an enhanced immune response that could protect against pathogenic microorganisms. In addition, the highest phagocytic activity was obtained with the dose of $10^{7} \mathrm{CFU} / \mathrm{g}$ and not by the dose of $10^{9} \mathrm{CFU} / \mathrm{g}$. This is in agreement with the study of Panigrahi et al. (2004) that phagocytic activity of rainbow trout, Oncorhynchus mykiss fed with two doses $\left(10^{9} \mathrm{CFU} / \mathrm{g}\right.$ and $\left.10^{11} \mathrm{CFU} / \mathrm{g}\right)$ of $L$. rhamnosus were significantly higher than control. However, the authors concluded that low dose bacterium would be sufficient to elicit the phagocytic activity of the leukocytes.

The only significant increase in serum acid phosphatase activity was observed in fish fed with $10^{9} \mathrm{CFU} / \mathrm{g}$ L. plantarum (NIOFSD018) that indicates the possible activation of this enzyme only with a high dose of this probiotic in 
fish diet. Similar to present findings, acid phosphatase activity was activated in Miichthys miiuy only by supplementation with the highest dose $\left(10^{9} \mathrm{CFU} / \mathrm{g}\right)$ of C. butyricum (Zeng-fu et al., 2006).

Lysozye activity of O. niloticus fed the lower dose $10^{7} \mathrm{CFU} / \mathrm{g}$ was found to be not significantly different from the value obtained by the higher dose $10^{9}$ $\mathrm{CFU} / \mathrm{g}$. Contrary to this result, the serum lysozyme activity was significantly greater in rainbow trout, O. mykiss fed the higher level $\left(10^{11} \mathrm{CFU} / \mathrm{g}\right)$ of probiotic bacteria L. rhamnosus (JCM 1136) compared with the control fish (Panigrahi et al., 2004). This difference in determining the optimum dose may be due to the difference in Lactobacillus species or fish species or to the difference in experimental duration.

Immunoglobulin results showed an improvement in the total immunoglobulin level by increasing the dose of L. plantarum (NIOFSD018) in the diet up to $10^{7} \mathrm{CFU} / \mathrm{g}$ after which the $\mathrm{Ig}$ level decreased. It is widely recognized that immunoglobulins provide disease protection to animals and humans. Some studies have also shown the effect of lactic acid bacteria in enhancing immunological factors such as Ig. In contrast to our results, the total immmunolglobulin level in rainbow trout was not significantly increased by the addition of different doses of $L$. rhamnosus (JCM 1136) to the diet (Panigrahi et al., 2004).

The results of the present study exhibited slight stimulation of phenoloxidase by increasing the dose of L. plantarum (NIOFSD018) in tilapia diet. However, in the trial of Zeng-fu et al. (2006), serum PO activity in Miichthys miiuy was significantly increased by an increase in the dose of $C$. butyricum added to the diet. Phenoloxidase (PO) is known to be an important enzyme in the defense mechanism of fish. Phenoloxidase activity is commonly used as an indicator of the immune response in shrimp and crab and the activity of this enzyme has been also detected in serum of fish, Miichthys miiuy (Zeng-fu et al., 2006). Phenoloxidase usually exists as an inactive precursor (proPO) (Smith and Säderhäll, 1991; Asokan et al., 1997), which can be readily activated to phenoloxidase (PO) by an endogenous activating system or exogenous elicitors such as trypsin, sodium dodecyl sulphate (SDS) (Asokan et al., 1997) and laminarin (Leonard et al., 1985). Phenoloxidase has been also found in neutrophils of O. niloticus (Witten et al., 1998).

It is clear from the present results that mean values of phagocytic activity, acid phosphatase activity, lysozyme activity and total immunoglobulin levels increased to different degrees depending on the dose of L. plantarum (NIOFSD018) compared to the control group. Phenoloxidase activity was slightly increased with the increase in the dose of probiotics. However, by attaining a dose of L. plantarum (NIOFSD018) up to $10^{9} \mathrm{CFU} / \mathrm{g}$ diet, a significant increase in acid phosphatase activity was observed. However, the other immunological parameters such as phagocytic activity and immunoglobulin level were significantly decreased by increasing the probiotic dose to $10^{9} \mathrm{CFU} / \mathrm{g}$. For lysozyme activity, no significant differences were detected 
between fish fed either $10^{7}$ or $10^{9} \mathrm{CFU} / \mathrm{g}$ diet of this probiotic. This suggests that with the exception of acid phosphatase, administration of a dose of $10^{7} \mathrm{CFU} / \mathrm{g}$ of $L$. plantarum (NIOFSD018) was sufficient to stimulate the immune system of tilapia and the higher dose of $10^{9} \mathrm{CFU} / \mathrm{g}$ should be considered as an overdose of this probiotic.

In conclusion, the present study indicates that administration of probiotics in fish diet have stimulatory effects on the immune system of the fish and can lead to improving the health of $O$. niloticus. It can be recommended to incorporate these probiotics as dietary supplements in commercial feeds or in the form of bacterial biofilm to achieve better colonization in the digestive tract of the fish.

\section{REFERENCES}

Alderman, D. J. and Hastings, T.S. (1998). Antibiotic use in aquaculture: development of antibiotic resistance - potential for consumer health risks. Internat. J. Food Scie. \& Tech, 33: 139-155.

Aly, S.M.; Ahmed ,Y.A.; Ghareeb , A. A. and Mohamed, M.F.(2008). Studies on Bacillus subtilis and Lactobacillus acidophilus, as potential probiotics, on the immune response and resistance of Tilapia nilotica (Oreochromis niloticus) to challenge infections. Fish and Shellfish Immunolo., 25: 128-136.

Amábile-Cuevas, C.; Gárdenas-Garciá, M. and Ludgar, M. (1995). Antibiotic resistance. Ameri. Sci., 83: 320-329.

American Public Health Association (APHA) (1995). Standard methods of the examination of water and wastewater $19^{\text {th }}$ edition. Washington, D.C

Anderson, D.P.; Siwicki, A.K. and Rumsey, G. L. (1995). Injection or immersion delivery of selected immunostimulants to trout demonstrate enhancement of nonspecific defense mechanisms and protective immunity. In: Shariff, M., Arthur, J.R., Subasinghe, R.P. (Eds.), Diseases in Asian Aquaculture: II. Fish Health Section. Asian Fisheries Society, Manila, pp. 413- 426.

Asokan, R.M.; Arumugam, M. and Mullalnadhan, P. (1997). Activation of prophenoloxidase in the plasma and haemocytes of the marin mussel Perna viridis Linnaeus. Developm. Compa. Immunolo., 21: 1-12

Austin B.; Stuckey, L.F.; Robertson, P.A.W.; Effendi, I. and Griffith D.R.W. (1995). A probiotic strain of Vibrio alginolyticus effective in reducing diseases caused by Aeromonas salmonicida, Vibrio anguillarum and Vibrio ordalii. J. fish dise., 18: 93-96. 
Brunt, J.; Newaj-Fyzal, A. and Austin, B. (2007). The development of probiotics for the control of multiple bacterial disease of rainbow trout, Oncorhynchus mykiss (Walbaum). J. Fish Dise., 30: 573-579.

Charteris, W.P.; Kelly, P.M.; Morelli, L. and Cllins, J.K. (1998). Antibiotic susceptibility of potentially probiotic Lactobacillus species. J. Food Protec., 61: 1634-1643.

Chipman, D.M. and Sharon, N. (1969). Mechanism of lysozyme action. Scie., 165: 454-465.

Cuesta, A.; Meseguer, J. and Esteban, M. A. (2004). Total serum immunoglobulin $\mathrm{M}$ levels are affected by immunomodulators in seabream (Sparus aurata L.). Veter. Immunolo. Immunopatholo., 101: 203-210.

Daboor, S. M. (2008). Microbiological Profiles of El-Qanater El-Khairia Fish Farm. Global Veteri., 2: 51-55.

Douglas, L. J. (1989). Adhesion to surfaces. In: Rose, A.H., Harrison, J.S. (Eds.), the Yeast. London, pp. 239-275.

Duncan, B. (1955). "Multiple range and multiple (F) tests". Biometrics, 11:1-42.

Ellis, A.E. (1999). Immunity to bacteria in fish. Fish and Shellfish Immunolo., 9: 291- 308 .

Engstad, R.E.; Robertsen, B. and Frivold, E. (1992). Yeast glucan induces increase in activity of lysozyme and complement-mediated haemolytic activity in Atlantic salmon blood. Fish \& Shellfish Immunolo., 2: $287-297$.

Food and Agriculture Organization of the United Nations (FAO) (2006). State of world aquaculture. Room : FAO fisheries, technical paper No. 500.

Gatesoupe F.J. (1999). The use of probiotics in aquaculture. Aquacul., 180: 147165.

Gildberg, A. and Mikkelsen, H. (1998). Effects of supplementing the feed to Atlantic cod (Gadus morhua) fry with lactic acid bacteria and immunostimulating peptides during a challenge trial with Vibrio anguillarum. Aquacul., 167: 103-113. 
Gill, H.S. (1998). Stimulation of the immune system by lactic culture. Internat. Dairy J., 8: 535-544.

Guarner, F. and Schaafsma, G. F. (1993). Probiotics. Internat. J. Food \& Microbio., 39: 237-238.

Gullian, M.; Thompson, F. and Rodriguez, J. (2004). Selection of probiotic bacteria and study of their immunostimulatory effect in Penaeus vannamei. Aquacul., 233: 1-14.

Hepher, B.; Liao, I.C.; Cheng, S.I.I. and Hsieh, C. S. (1983). Food utilization by red tilapia. Effect of diet composition, feeding level and temperature on utilization efficiencies for maintenance and growth. Aquacul., 32: 255275 .

Heyman, M. and Me'nard, S. (2002). Probiotic microorganisms: how they affect intestinal pathophysiology. Cellul. \& Molec. Life Scie., 59: 1-15.

Holt, J.G.; Krieg, N.R.; Sneath, P.H.A.; Staley, J.T. and Williams, S.T. (1994). Bergey's Manual of Determinative Bacteriology. $9^{\text {th }}$ ed. Maryland, USA: Williams \& Wilkins, Baltimore. pp 787.

Hutchinson, T.H. and Manning, M.J. (1996). Seasonal trends in serum lysozyme activity and total protein concentration in dap (Limanda limanda L.) sampled from Lyme Bay, UK. Fish and Shellfish Immunolo., 6: 473-482.

Irianto, A. and Austin, B. (2002). Use of probiotics to control furunculosis in rainbow trout, Oncorhynchus mykiss (Walbaum). J. Fish Dise., 25: 333342 .

Jørgensen, J.B.; Lunde, H. and Robertsen, B. (1993). Peritoneal and head kidney cell response to intraperitoneally injected yeast glucan in Atlantic salmon. J. Fish Dise., 16: 313-325.

Kennedy, S.B.; Tucker, J.W.; Neidic, C.L.; Vermer, G.K.; Cooper, V.R. and Jarrell, J.L.(1998). Bacterial management strategies for stock enhancement of warmwater marine fish: a case study with common snook (Centropomus undecimalis). Bull. Mari. Scie., 62: 573-88.

Kesarcodi-Watson, A.; Kaspar, H.; Lategan, M. J. and Gibson, L. (2008). Probiotics in aquaculture: the need, principles and mechanisms of action and screening processes. Aquacul., 274: 1-14. 
Leonard, C.; Söderhäll, K. and Ratcliffe, N. K. (1985). Studies on prophenoloxidase and protease activity of Blaberus craniifer haemolymph. Inse.Biochemi., 15: 803-810.

Li, P.; Lewis, D.H. and Gatlin, D.M. (2004). Dietary oligonucleotide influences immune responses and resistance of hybrid striped bass (Moronic chrysops $\times$ M. saxatilis) to Streptococcus iniae infection. Fish and Shellfish Immunol., 16: 561-569.

Li, P.; Burr, G.S.; Goff, J.; Whiteman, K.W.; Davis, K.B.; Vega, R.R.; Neill, W.H. and Gatlin III, D.M. (2005). A preliminary study on the effects of dietary supplementation of brewers yeast and nucleotides, singularly or in combination, on juvenile red drum (Sciaenops ocellatus). Aquacul. Rese., 36:1120-1127.

Matsuzaki, T. and Chin, J. (2000). Modulating immune responses with probiotic bacteria. Immunolo. \& Cell Biolo., 78: 67-73.

Miettinen, M.; Vuopio-Varkila, J. and Varkila, K. (1996). Production of human tumor necrosis factor alpha, interleukin-6, and interleukin- 10 is induced by lactic acid bacteria. Infec. \& Immuni., 64: 5403-5405.

Moriarty D.J.W. (1998). Control of luminous Vibrio species in penaeid aquaculture ponds. Aquacul., 164: 351-358.

Moyner, K.; Roed, K.H.; Sevatdal, S. and Heum, M. (1993). Changes in nonspecific immune parameters in Atlantic salmon, Salmo salar L., induced by Aeromonas salmonicida infection. Fish \& Shellfish Immunolo., 3: $253-265$

Nayak, S.K. (2010). Probiotics and immunity: A fish perspective. Fish and Shellfish Immunolo., 29: 2-14.

Nayak, S.K.; Swain, P.; and Mukherjee, S. C. (2007). Effect of dietary supplementation of probiotic and vitamin $\mathrm{C}$ on the immune response of Indian major carp, Labeo rohita (Ham.). Fish and Shellfish Immunolo., 23: 892-896.

Nikoskelainen, S.; Ouwehand, A.C.; Bylund, G. and Salminen, S. (2001). Protection of rainbow trout (Oncorhynchus mykiss) from furunculosis by Lactobacillus rhamnosus. Aquacul., 198: 229-236. 
Nils, H.A. (1983). Handbook of immunoprecipitation- in Gel Techniques. Published by Blackwell Scientific publications, Oxford, London. Edinburgh Roston Melbourne. PP: 7-21.

Ortuño, J.; Cuesta, A.; Rodríguez, A.; Esteban, M. A. and Meseguer, J. (2002). Oral administration of yeast, Saccharomyces cerevisiae, enhances the cellular innate immune response of gilthead seabream (Sparus aurata L.). Veterinary Immunolo. and Immunopatholo., 85: 41-50.

Panigrahi, A.; Kiron, V.; Kobayashi, T.; Puangkaew, J.; Satoh, S. and Sugita, H. (2004). Immune responses in rainbow trout Oncorhynchus mykiss induced by a potential probiotic bacteria Lactobacillus rhamnosus JCM 1136. Veteri.Immunolo.\& Immunopatholo., 102: 379-388.

Panigrahi, A.; Kiron, V.; Puangkaewa, J.; Kobayashib, T.; Satoh, S. and Sugita, H. (2005). The viability of probiotic bacteria as a factor influencing the immune response in rainbow trout Oncorhynchus mykiss. Aquacul., 243: 241- 254.

Parry, R.M.; Chandan, R. C. and Shahani, K.M.(1965). A rapid and sensitive assay of muramidase. Procee. Socie. Experimen. Biolo. Medi., 119: 384386.

Pieters, N.; Brunt, J.; Austin, B. and Lyndon, A. R. (2008). Efficacy of in-feed probiotics against Aeromonas bestiarum and Ichthyophthirius multifiliis skin infections in rainbow trout (Oncorhynchus mykiss Walbaum). Appli. Microbiolo., 105: 723-732.

Puangkaew, J.; Kiron, V.; Somamoto,T.; Okamoto, N.; Satoh, S.; Takeuchi, T. and Watanabe, T.(2004). Nonspecific immune response of rainbow trout (Oncorhynchus mykiss. Walbaum) in relation to different status of vitamin E and highly unsaturated fatty acids. Fish \& shellfish Immunolo.,16: 2539.

Querroz, J.F. and Boyd, C.E. (1998). Effects of a bacterial inoculum in channel cat fish ponds. J. World Aquacul. Soci., 29: 67- 73.

Rengpipat, S.; Rukpratanporn, S.; Piyatiratitivorakul, S. and Menasaveta, P. (2000). Immunity enhancement in black tiger shrimp (Penaeus monodon) by a probiont bacterium (Bacillus S11). Aquacul., 191:271288. 
Sakai, M.; Taniguchi, K.; Mamoto, K.; Ogawa, H. and Tabata, M. (2001). Immunostimulant effects of nucleotide isolated from yeast RNA on carp, Cyprinus carpio L. J. Fish Dise., 24: 433-438.

Salinas, I.; Cuesta, A.; Esteban, M.A. and Meseguer, J. (2005). Dietary administration of Lactobacillus delbru"eckii and Bacillus subtilis, single or combined, on gilthead seabream cellular innate immune responses. Fish and Shellfish Immunolo., 19: 67-77.

Schltz, L. A. (1987). Methods in Clinical Chenistry. The C.V. Mosby Cost Louis: $742-746$.

Siwicki, A. K.; Anderson, D.P. and Rumsey, G.L. (1994). Dietary intake of immunostimulants by rainbow trout affects non-specific immunity and protection against furunculosis. Veteri. Immunolo. \& Immunopatholo., 41: 125-139.

Siwicki, A. K. and Studnicka, M. (1987). The phagocytic activity of neutrophils and serum lysozyme activity in experimentally infected carp, Cyprinus carpio L. J. Fish Biolo., 31: 57- 60.

Smith, V.J. and Säderhäll, K. J. (1991). A comparison of phenoloxidase activity in the blood of marine invertebrates. Developm. \& Compa. Immunolo., 15: $251-261$

Stosik, M. and Szenfeld, J. (1996). Use of CERBIO probiotic in carp nutrition. Med. Weter 52: 467-469.

Sugita, H.; Miyajima, C. and Deguchi, Y. (1991). The vitamin B -producing ability of the intestinal microflora of freshwater fish. Aquacul., 92: 267276.

Sung, H.H. and Song, Y.L. (1996) Tissue localization of Vibrio antigen delivered by immersion to tiger shrimp (Penaeus monodon). Aquacut., 145: 41-54.

Sung, H.H.; Yang, Y.L. and Song, Y.L. (1996). Enhancement of microbicidal activity in the tiger shrimp Penaeus monodon via immunostimulation. J. Crustac. Biolo., 16: 278-284

Taoka, Y.; Maeda, H.; Jo, J.Y.; Kim, S.M.; Park, S.I.; Yoshikawa, T. and Sakata, T. (2006). Use of live and dead probiotic cells in tilapia, Oreochromis niloticus. Fisheri. Scie., 72: 755-766. 
Thanardkit, P.; Khunrae, P.; Suphantharika, M. and Verduyn, C. (2002). Glucan from spent brewer's yeast: preparation, analysis and use as a potential immunostimulants in shrimp feed. World J. Microbiolo. \& Biotechnolo., 18: 527-539.

Teuber, M. (2001). Veterinary use and antibiotic resistance. Current Opinion Microbiolo., 4: 493-499.

Trust, T. J. and Sparrow, R.A.H. (1974). The bacterial flora in the alimentary tract of freshwater salmonid fishes. Canad. J. Microbiolo., 20: 1219-1228.

Vázquez-Juárez, R.; Andlid, T. and Gustafsson, L. (1997). Adhesion of yeast isolated from fish gut to crude intestinal mucus of rainbow trout, Salmo gairdner. Molecu. Mar. Biolo. Biotechnolo., 6: 64-71.

Verschuere, L.; Rombaut, G.; Sorgeloos, P. and Verstraete, W. (2000). Probiotic bacteria as biological control agents in aquaculture. Microbiolo. Molecu. Biolo. Revi., 64: 655-671.

Vine, N.G.; Leukes, W.D. and Kaiser, H. (2004). In vitro growth characteristics of five candidate aquaculture probiotics and two fish pathogens grown in fish intestinal mucus. FEMS Microbiolo.Lett., 231: 145-152.

Watts, M.; Munday, B.L. and Burke, C.M. (2001). cDNA sequences and organization of $\operatorname{IgM}$ heavy hain genes in two holostean fish. Developm.\& Compara. Immunolo., 19: 153-164.

Witten, P.E.; Renwrantz, L. and Villwock, W. (1998). Haematogram of the tilapia Oreochromis niloticus (Cichlidae, Teleostei) and application of a putative phenoloxidase for differentiating between neutrophilic granulocytes and monocytes. Canad. J. Zoolo., 76: 310-319.

Yoshida, T.; Kruger, R. and Inglis, V. (1995). Augmentation of non-specific protection in African catfish, Clarias gariepinus (Burchell), by the longterm oral administration of immunostimulants. J. Fish Dise., 18: 195-198.

Zeng-fu, S.; Tian-xing, W.U.; Li-sheng,C.; Li-jing,Z. and Xiao- dong, Z. (2006). Effect of dietary supplementation with Clostridium butyricum on the growth performance and humoral immune response in Miichthys miiuy. J. Zhejiang Universi. Scie. (B) 7: 596-602. 